\title{
REPRESENTASI IMAN KRISTEN DI NEGARA SEKULER: ANALISIS WACANA FILM GOD'S NOT DEAD
}

\author{
Yuangga Kurnia Yahya \\ Universitas Darussalam Gontor \\ Yuangga4@unida.gontor.ac.id
}

\begin{abstract}
ABSTRAK
Film merupakan salah satu media komunikasi massa yang juga merupakan produk budaya populer. Pada saat ini, film juga memiliki andil yang besar dalam mengkonstruksi berbagai realitas. Beberapa realitas yang ada di film seringkali menyingkap hal-hal yang tidak terlalu tampak di masyarakat umum, salah satunya adalah masalah keagamaan dan keimanan. Objek pembahasan ini adalah Trilogi film God's Not Dead (2014), God's Not Dead 2 (2016), dan God's Not Dead: A Light in Darkness (2018).

Artikel ini merupakan hasil dari studi kualitatif menggunakan pendekatan analisis wacana model Teun A Van Dijk. Wacana dalam film tidak cukup disandarkan pada teks semata karena ia terdiri dari berbagai struktur dan tingkatan. Struktur tersebut adalah struktur makro, super struktur, dan struktur mikro.

Dari hasil penelitian ditemukan bahwa penyusunan wacana cukup terstruktur, mulai dari struktur Tematik, Struktur Skematik, Struktur Semantik, Struktur Sintaksis, Struktur Stilistik, dan struktur retorisnya. Struktur Makro meliputi struktur tematik, super struktur meliputi struktur skematik, adapun sisanya termasuk dalam struktur mikro. Kedua unsur dari struktur tersebut menunjukkan bahwa film ini memang menyampaikan pesan nyata bahwa Tuhan tetap memiliki tempat di kehidupan manusia meskipun hidup di lingkungan yang sangat rasional dan tidak melibatkan Tuhan dalam kehidupan mereka.
\end{abstract}

Kata kunci: Teisme, Iman Kristen, Film, Analisis Wacana.

\section{PENDAHULUAN}

Salah satu media komunikasi massa di zaman modern ini adalah film. Di era digital ini, pesan yang disampaikan melalui sebuah tayangan televisi atau berbentuk film dapat disampaikan kepada berbagai kalangan masyarakat dengan waktu yang singkat. Hal tersebut merupakan hal yang tidak mungkin dilakukan oleh berita tertulis (Nayyar, 2007: 4). Selain itu, berita yang disampaikan oleh film lebih kompleks dari berita yang tertulis karena pesan yang disampaikan dapat berupa verbal dan non-verbal. Pesan verbal terdiri dari dialog, narasi, dan tulisan. Adapun pesan non-verbal dapat berupa perilaku, karakter, ekspresi, penampilan, pencahayaan, sudut pengambilan gambar, music latar, warna, dan tanda lain yang memiliki arti tertentu dalam film tersebut (Surwati, 2012: 3-4). Film juga merupakan produk budaya populer yang memiliki dua fungsi, yaitu sebagai konstruksi realitas dan representasi realitas sosial budaya

Artikel ini akan dimulai dengan dikotomi dunia Barat dan Timur yang merupakan budaya warisan era kolonial. Dikotomi tersebut pada akhirnya melahirkan strereotyping masing-masing pihak. Bangsa Timur selalu memandang Barat sebagai negara-negara yang kapitalis, rasional, sekuler, dan tidak bersifat Teistik dalam memandang segala sesuatu (Zarkasyi, 2013: 26). Barat adalah wilayah di mana konsep tentang ketuhanan, ilmu dan realitas tidak muncul dalam pandangan hidup beragama (Zarkasyi, 2013: 22). Bahkan lebih jauh, tidak sedikit cendekiawan Timur yang menyatakan bahwa identitas kultural masyarakat Barat adalah The Civilization of Capitalism dan bukan bersandar pada Katolik atau Protestan (Zarkasyi, 2013: 16).

Film 'God's Not Dead' yang diproduksi oleh Pure Flix Entertainment di Amerika Serikat merupaka $\mathrm{n}$ film yang bercerita tentang iman umat Kristiani di tengah negara yang dilabeli sebagai negara sekuler, bebas agama, dan tidak memiliki tempat untuk hal-hal metafisik seperti keimanan dan ketuhanan. Film ini mengangkat beberapa realitas permasalahan umat Kristiani dalam menampakkan identitas keagamaan mereka dalam masyarakat Barat. Karenanya film ini dipilih untuk menjadi salah satu representasi umat Kristen di negara Barat yang 'sekuler'.

Artikel ini akan meneliti representasi keimanan Kristen di film tersebut dengan menggunakan analisis wacana model Teun A Van Dijk. Dengan pendekatan tersebut, diharapkan berbagai representasi dan pesan dari realitas sosial yang ditunjukkan di dalam film tersebut dapat tertangkap, baik dalam makro struktur, super struktur, maupun mikro struktur. 


\section{METODOLOGI}

Penelitian berfokus pada dialog dan teks yang terdapat dari film dengan beberapa alasan. Pertama, bahasa bukanlah media komunikasi yang terlepas dari dunia nyata. Ia merupakan 'mesin' yang menciptakan dan mengkonstruk dunia sosial (Jorgensen dan Phillips, 2002: 8-9; Hamad, 2007: 336). Hal tersebut tidak menunjukkan bahwa realitas tidak nyata. Makna dan representasi adalanya nyata. Objek fisik juga nyata, namun keduanya hanya dapat bertemu melalui pendekatan wacana (Jorgensen dan Phillips, 2002: 9). Kedua, bahasa merupakan refleksi dari sikap hidup dan tingkah laku. Dari gaya bahasa yang digunakan, penekanan, dan pengulangan, dapat diketahui sisi kekuatan (power), afiliasi (affiliation), daya tarik (attraction), kepentingan (interest), dan rasa tanggungjawab (responsibility) (Adler dan Rodman, 2006: 85-88).

Van Dijk membuat kerangka analisis yang tidak hanya menyoroti teks dalam suatu film, namun juga terdiri atas 3 struktur. Keseluruhan struktur tersebut saling mendukung satu sama lain. Struktur tersebut adalah (Sobur, 2001: 74):

1. Struktur makro. Struktur ini merupakan makna umum dan global dari suatu teks yang dapat dipahami dengan melihat topi dari suatu teks atau salah satu sisi tertentu dari suatu teks (Van Dijk, 1992: 6). Dalam penelitian ini, struktur ini dapat dilihat dari topik.

2. Super struktur. Struktur ini merupakan kerangka suatu teks di mana struktur dan elemen wacana dalam teks disusun secara utuh.

3. Struktur mikro. Struktur ini adalah mengamati makna dalam teks dengan menganalisis kata, kalimat, proposisi, dan lain sebagainya (Van Dijk, 1992: 7).

Dari ketiga struktur tersebut, ditemukan beberapa hal yang perlu diamati dalam menemukan wacana film ini. Struktur makro berkaitan dengan tematik atau topik 'Apa yang dikatakan'. Super struktur berkaitan dengan skematik atau topik 'Bagaimana pendapat tersebut disusun?'. Struktur mikro berkaitan dengan beberapa hal seperti semantik (makna dalam teks), sintaksis (bagaimana pendapat disampaikan), stilistik (pilihan kata apa yang dipakai), dan retoris (bagaimana dan cara apa penekanan dilakukan) (Van Dijk, 1992: 12-13).

\section{BARAT ADALAH NEGARA SEKULER}

Judul tersebut merupakan sebuah ekspresi pengalaman mayoritas bangsa Timur dalam memandang Barat. Istilah Barat-Timur sendiri merupakan warisan era kolonialisme dan komunisme. Dikotomi tidaklah berdasarkan letak geografis, namun lebih kepada alasan kebudayaan (cultural). Karenanya, negara-negara Islam dianggap sebagai Timur meskipun membentang dari Afrika Utara hingga Indonesia dan Australia tetap dianggap sebagai Barat (Mestrovic, 2005: 61).

Dalam era selanjutnya, sebagai efek dari dikotomi tersebut, tulisan dan diskusi ilmiah tetap hidup dalam makna Barat dan Timur. Perbedaan yang kontras antara keduanya masih sering terlihat hingga saat ini. Budaya Timur "dianggap" mementingkan kehidupan kerohanian, mistik, pikiran prelogis, keramahtamahan, dan gotong royong, adapun budaya Barat lebih mementingkan kebendaan, pikiran logis, hubungan asasguna (hanya berdasar pada prinsip guna), dan individualisme (Koentjaraningrat, 1981: 132).

Dalam ranah pemikiran dan hubungan antar agama, pandangan hidup Barat berbasis materialisme, pragmatisme, filsafat sekuler, dan berujung pada pemusnahan ajaran agama (Imaduddin, 2017: 107).Identitas kebudayaan Barat juga tidak berdasar pada ajaran agama, baik Katolik maupun Protestan, melainkan pada semangat kapitalisme (Zarkasyi, 2013: 16). Pendek kata, ideologi dan peradaban Barat 'dianggap' selalu menyingkirkan segala hal metafisik, termasuk agama dan Tuhan dalam aspek negara, pendidikan, moralitas, dan segala aspek kehidupan (Fata dan Noorhayati, 2016: 219).

Berbagai alasan tersebut mendasari stigma negatif kehidupan tanpa Tuhan di Barat. Melalui film 'God's Not Dead', pembuat film seolah menyuarakan kepada dunia bahwa Tuhan 'masih' ada dan bertahta di hati orang-orang beriman. Sekulerisme yang seringkali dituduhkan kepada seluruh masyarakat Barat nyatanya tidak sepenuhnya benar. Karenanya, penulis mencoba menangkap wacana tersebut. Dengan demikian, pembaca dapat mendapatkan info yang benar, sebagaimana masyarakat merasakannya atau 'back to things itself' (Yahya, 2018: 244).

\section{ANALISIS WACANA FILM GOD'S NOT DEAD}

Dalam memahami pesan komunikasi dan wacana yang dibangun di film tersebut, peneliti menggunakan model analisis wacana Teun A. Van Dijk. Dalam usaha memahami sebuah wacana, Van Dijk menggunakan enam unsur, yaitu segi tematik, segi skematik, segi semantik, segi sintaksis, segi stilistik, dan segi retoris. Berikut adalah beberapa analisa percakapan di fim tersebut. 


\section{STRUKTUR TEMATIK}

Struktur ini merupakan struktur makro wacana dalam sebuah film. Ketiga film tersebut mengangkat tema yang sama, yaitu masalah keimanan penganut Kristen dalam kehidupan di negara Barat. Masing-masing film memiliki fokus yang berbeda-beda. Di film pertama, tema yang diangkat adalah kedudukan agama dan ilmu pengetahuan. Bagaimanapun seorang ilmuwan dan suatu ilmu mengingkari eksistensi Tuhan, fakta ilmiah yang rasional akan selalu mengarah pada pengakuan keberadaan Tuhan.

Dalam film kedua, tema yang diangkat adalah kebebasan berbicara tentang agama di ruang publik dan hubungan antara Yesus dengan sejarah. Banyak yang meyakini bahwa Yesus hanyalah sekedar khayalan umat Kristiani dan Dia tidak pernah eksis di kehidupan ini. Berbicara tentang Yesus berarti berbicara tentang mitos dan takhayul. Dalam film ini, keyakinan tersebut ditentang dengan menggunakan berbagai fakta sejarah bahwa Yesus adalah nyata dan termasuk tokoh yang berpengaruh dalam rentetan perjalanan dunia.

Kedua pesan yang ingin disampaikan di kedua film tersebut adalah agama tidak bertentangan dengan ilmu pengetahuan dan sejarah. Kedua hal tersebut adalah pembicaraan yang sering dihubunghubungkan dengan pandangan sekuler. Sesuai sejarah lahirnya, sekulerisme sendiri memang sebuah upaya memisahkan agama dari berbagai segi kehidupan manusia, termasuk ilmu pengetahuan dan sejarah. Melalui kedua film tersebut, pesan bahwa agama dapat berjalan berdampingan dengan ilmu pengetahuan dan sejarah terasa kuat. Dengan kata lain, ketika seseorang ingin memperdalam ilmu pengetahuan dan sejarah, ia tidak perlu menanggalkan keimanan yang ia miliki.

Di film ketiga, tema yang diangkat lebih mendasar, yaitu bagaimana bersikap sebagaimana yang diajarkan Yesus. Di sini Pendeta Dave digambarkan sebagai seorang pendeta yang selalu dekat dengan Tuhan dan memberikan khotbah keagamaan kepada jema'atnya. Namun ia tetap manusia biasa yang seringkali merasa bangga secara berlebih dan merasa berhak untuk membenci mereka yang berbuat jahat kepadanya. Hingga di akhir film, Pendeta tersebut menemukan pesan-pesan kebaikan Yesus yang kadangkala ia lupakan.

\section{STRUKTUR SKEMATIK}

Struktur yang dimaksud di sini adalah bagaimana alur atau susunan teks wacana dibuat. Teks wacana tersebut biasanya dimulai dari pendahuluan, isi wacana, dan penutup, serta bagaimana summary dan story yang mendukung tema wacana. Struktur ini merupakan superstruktur yang menggambarkan bentuk umum dari suatu teks dalm film ini. Dalam analisisnya, judul film tersebut "God's Not Dead" merupakan sebuah pernyataan dan jawaban bagi mereka yang masih ragu akan keberadaan Tuhan dan karyaNya di dunia ini.

Berikut adalah beberapa dialog yang membawa wacana sebagaimana yang tertera dalam judul film tersebut:

- Dialog antara Martin Yip dan ayahnya via telepon. Martin Yip berkata: "Aku sudah lulus beberapa mata kuliah, termasuk matematika dan kimia. Tapi salah satu mata kuliah pilihanku, perkenalan filsafat, banyak membahas Tuhan". Ayahnya berkata dengan wajah cemas: "Tuhan? Kenapa membahas Tuhan?". Martin pun menjawab: "Ada banyak pendapat yang menyatakan keberadaanNya". Ayahnya bertanya lagi: "Apa pendapat profesormu?". Martin menanggapi: "Dia sangat yakin bahwa Tuhan tidak ada". Ayahnya pun menimpali seraya mengakhiri perbincangan: "Berarti itu tidak jadi masalah, Tuhan tidak ada. Ayah sedang sibuk, ayah harus bekerja". (God's Not Dead 1)

- Profesor Radisson berargumen tentang agama di suatu sesi diskusi: "Karena agama itu, seperti virus pikiran yang ditinggalkan orang tua bagi anak mereka, dan kekristenan adalah virus terburuk di dunia ini. Perlahan-lahan merayap ke dalam hidup kita saat kita lemah atau sakit atau tak berdaya". Josh Wheaton menanggapi: "Jadi, agama itu seperti penyakit?". Profesor Radisson menjawab:" Ya. Benar, menginfeksi segalanya". (God's Not Dead 1)

Dialog-dialog di atas menunjukkan beberapa pertanyaan dan sanggahan terkait keberadaan Tuhan yang dijawab dengan tegas melalui judul film tersebut.

\section{STRUKTUR SEMANTIK}

Dalam struktur ini, analisis berfokus pada makna yang ditekankan dalam sebuah teks. Elemen ini membahasa tentang hubungan antar kalimat yang mempunyai makna tertentu dalam bangunan. Berikut adalah beberapa dialog yang memiliki makna tersirat atau tersurat terkait film tersebut: 
- Setelah melewati banyak masalah, Pendeta Dave bertemu dengan Pendeta Roland Dial lagi. Pendeta Roland bertanya: "Bagaimana kabarmu?". Pendeta Dave menjawab: "Aku baik-baik saja". Lalu pendeta Roland berkata lagi: "Kau yakin kau baik-baik saja setelah banyak hal yang terjadi di televisi dan persengketaanmu dengan Tom Ellsworth dan sekarang dengan anak ini?". Pendeta Dave mencoba berkilah: "Aku tidak meminta semua perseteruan ini". Pendeta Roland kembali menasehatinya: "Tapi itulah kenyataannya. Kau harus berfokus pada apa yang penting. Orang-orang banyak tertarik dengan Yesus karena cinta kasihNya, kebaikanNya, dan kesabaranNya. Dia selalu menyampaikan kebenaran tanpa menjatuhkan dirinya dalam posisi tawar-menawar. Dia selalu bersikap lembut kepada mereka yang lemah dan keras kepada mereka yang arogan. Ketika Ia berbicara dengan orang bodoh, Ia bersabar dan tidak pernah menjadikan dirinya termasuk orang bodoh. Ia juga tidak pernah merasa bangga diri, David". (God's Not Dead 3)

\section{STRUKTUR SINTAKSIS}

Aspek yang diliha dalam struktur ini adalah penggunaan bentuk kalimat koherensi dan kata ganti. Elemen bentuk kalimat dan koherensi dititiktekankan pada suatu pertalian atau kalimat berbentuk kata. Koherensi adalah pautan antar gagasan yang menyusun sebuah wacana. Berikut adalah dialog yang menunjukkan hubungan koherensi dan kata ganti:

- Dalam akhir diskusi, Josh Wheaton bertanya kepada Prof. Radisson: "Siapa sebenarnya yang ingin anda buat gagal, Profesor? Aku atau Tuhan?". Setelah suasana hening sepersekian detik, Josh Wheaton bertanya lagi: "Apa anda membenci Tuhan?". Prof. Radisson menjawab: "Itu bukan lagi pertanyaan". Josh mengulangi: "Baiklah, mengapa anda membenci Tuhan? Tolong jawab pertanyaannya! Anda tahu ilmu pengetahuan dan segala argumen. Ilmu pengetahuan mendukung keberadaanNya. Anda tahu kebenaran itu. Lalu, mengapa anda membenci Dia? Mengapa?". Prof. Radisson menjawab dengan penuh emosi: "Karena Ia telah mengambil segalanya dariku. Benar, aku membenci Tuhan. Hanya rasa benci yang aku punya". Josh Wheaton menutup diskusi dengan pertanyaan menohok:"Bagaimana bisa anda membenci seseorang jika orang itu tidak ada?" (God's Not Dead 1)

\section{STRUKTUR STILISTIK}

Aspek yang ditekankan dalam elemen ini adalah pilihan kata yang digunakan untuk mengkonstruksi wacana. Analisis difokuskan pada gaya bahasa yang digunakan oleh penulis atau pembicara untuk menyampaikan maksudnya. Berikut adalah contoh gaya bahasa yang digunakan dalam dialog:

- Pendeta Jude berkata kepada Pendeta Dave dengan sedikit sindiran dan juga motivasi ketika mobil mereka mogok sejak pagi: "David, kita sudah habiskan seluruh hidup kita membahas tentang iman. Sekarang aku memintamu menunjukkan iman itu". Ia menjawab: "Baiklah" dan mencoba menyalakan mobilnya. Setelah mobil tersebut dapat menyala, Dave berkata: "Mustahil". Jude segera membantahnya dan berkata: "Bukan. Iman". (God's Not Dead 1)

\section{STRUKTUR RETORIS}

Struktur ini berfokus pada bagaimana dan dengan cara apa penekanan dilakukan. Retoris juga berarti kalimat pertanyaan yang tidak memerlukan suatu jawaban. Berikut adalah dialog yang berisi kalimat pertanyaan retoris:

- Josh Wheaton menutup diskusi dengan pertanyaan menohok kepada Prof. Radisson:'Bagaimana bisa anda membenci seseorang jika orang itu tidak ada?" (God's Not Dead 1)

- Dalam sebuah wawanca di televisi, sang pembawa acara bertanya: "Apakah kau percaya bahwa dia berkhotbah kepada murid-muridnya?". Ia menjawab: "Gubernur, tidak sama sekali. Yesus Krsitus adalah orang yang paling berpengaruh yang pernah hidup. Bagaimana kamu bisa mengabaikan kebenaran itu dan tidak mengajar sejarahNya?". (God's Not Dead 2)

\section{PENUTUP}

Penelitian ini menunjukkan bahwa penulis skenario dan sutradara film tersebut ingin menyampaikan bahwa beragama di Barat adalah sah-sah saja. Meskipun ada beberapa kesulitan yang dihadapi, namun iman Kristen tetap bisa bertahan di sana. Panggilan nurani manusia untuk beragama dan bertuhan adalah sebuah kewajaran, tanpa memandang kondisi sosial masyarakat yang berada di tempat tersebut.

Setelah banyaknya pendapat terkait sekulerisme di Barat, film ini menjadi antitesis dari ketiadaan Tuhan dan agama di Barat. Melalui film ini realitas yang sering tertutupi oleh berbagai stigma buruk dan 
stereotyping di Barat dimunculkan. Peneliti mencoba memahami pesan dan wacana tersebut dengan analisis wacana model Van Dijk.

Film God's Not Dead merupakan sebuah representasi keimanan Kristen di negara Barat. Film adalah sebuah representasi dari realita sosial budaya yang mungkin tidak diketahui banyak orang. Isi film sendiri adalah rekaman dari realitas yang tumbuh dan berkembang di masyarakat dan kemudian diproyeksikan ke dalam bentuk audio dan visual. Film tidak terlepas dari realitas yang ada di kehidupan nyata. Sebagaimana film ini, merupakan jawaban bagi mereka yang menganggap Tuhan telah mati di negara-negara Barat dan juga sebagai penguat iman bagi umat Kristen bahwa keimanan mereka tak lekang oleh waktu, tidak bertentangan dengan ilmu pengetahuan maupun fakta empiris. Bahkan, pesan lebih jauh yang ingin disampaikan melalui film ketiga adalah betapapun seorang umat Kristen menghadirkan iman dalam kehidupan mereka, bila tanpa dibarengi rasa cinta kasih sesama makhluk dan manusia, rasa rendah diri, dan rasa saling menghargai tidaklah berarti apa-apa.

Hasil analisis di atas menunjukkan bahwa mulai dari tataran struktur makro, super struktur, hingga struktur mikro, semuanya membentuk satu alur dan satu wacana. Wacana tersebut menggiring opini penonton yang beragama Kristen untuk semakin memperkuat keimanan mereka. Audio, visual, dan bahasa verbal yang disajikan juga mengarah pada satu wacana tersebut. Adapun bagi penonton yang non Kristen dan bukan dari Barat, film tersebut menjadi narasi tandingan (counter narrative) terkait isu sekulerisme di negara-negara Barat.

\section{DAFTAR PUSTAKA}

Adler, Ronald B. dan George Rodman. 2006. Understanding Human Communication, Ninth Edition. New York: Oxford University Press.

Arnold, Gordon B. 2008. Conspiracy Theory In Film, Television, and Politics. United States: Greenwood Publishing Group, Inc.

Casebier, Allan. 2009. Film and Phenomenology: Toward a Realist Theory of Cinematic Representation. Cambridge: Cambridge University Press.

Djatmiko, Achmad. 2017. Kebangkitan Agama dan Prasangka Sekuler Dalam Kajian Hubungan Internasional dalam Jurnal Politika Vol. 8, No. 1, April 2017. 5-18.

Dzulfaroh, Ahmad Naufal. 2018. Respon Estetis Dalam Adaptasi Novel-Film Al-Fil Al-Azraq, dalam Jurnal Leksema, Vol. 3, No. 2, Juli-Desember 2018, 157-168.

Fata', Ahmad Khoirul dan Siti Mahmudah Noorhayati. 2016. Sekularisme dan Tantangan Pemikiran Islam Kontemporer, dalam Jurnal Madania, Vol. 20, No. 2, Desember 2016, 215-228

Fauzi, Imam. 2009. Pesan Dakwah Melalui Film (Analisis Wacana Film Do'a Yang Mengancam), Skripsi IAIN Sunan Ampel, Surabaya.

Hamad, Ibnu. 2007. Lebih Dekat Dengan Analisis Wacana dalam Jurnal Mediator Vol. 8, No. 2, Desember 2007, 325-344.

Imaduddin, Mujahid. 2017. Dampak Liberalisasi Pemikiran Islam terhadap Kehidupan Sosial, dalam Kalimah: Jurnal Studi Agama dan Pemikiran Islam, Vol. 15, No.1, Maret 2017, 91-116.

Jorgensen, Marianne dan Louise J. Phillips. 2002. Discourse Analysis as Theory and Method. London: SAGE Publications.

Koentjaraningrat. 1981. Kebudayaan Mentalitas dan Pembangunan. Jakarta: PT Gramedia.

Mestrovic, Stjepan G. 2005. The Balkanization of The West: The Confluence of Postmodernism and Postcommunism. London: Routledge.

Nayyar, Deepak. 2007. Modern Mass Communication (Concepts and Processes). Jaipur: Oxford Book Company.

Sobur, Alex. 2001. Analisis Teks Media: Suatu Pengantar Untuk Analisis Wacana, Analisis Semiotik, dan Analisis Framing. Bandung: Remaja Rosdakarya.

Surwati, Chatarina Heny Dwi. 2012. Konstruksi Feminisme dalam Film Indonesia (Analisis Wacana Kritis Konstruksi Feminisme dalam Film Indonesia Karya Nia Dinata) dalam Jurnal Komunikasi Massa, Vol 1, No. 1 tahun 2012, Program Studi Ilmu Komunikasi FISIP UNS.

Van Dijk, Teun. A. 1992. Text and Context: Explorations in the Semantics and Pragmatics of Discourse. London: Longman Group UK Limited.

Yahya, Yuangga Kurnia. 2018. Phenomenological Approach in Interfaith Communication: A Solution to Allegation of Religious Blasphemy in Indonesia dalam Jurnal Al-Tahrir IAIN Ponorogo, Vol. 18, No. 2, November 2018, 237-254.

Zarkasyi, Hamid Fahmi. 2013. Worldview Islam dan Kapitalisme Barat dalam Jurnal Tsaqafah Vol. 9, No. 1, April 2013, 15-38. 